\title{
PENGARUH MEDIA PEMBELAJARAN KOMIK TERHADAP HASIL BELAJAR SISWA AKUNTANSI DI SMK PGRI 1 PALEMBANG TAHUN PELAJARAN 2019/2020
}

\author{
Oleh: Luluk Irawan ${ }^{1}$, Erma Yulaini ${ }^{2}$, Januardi $^{3}$ \\ (UNIVERSITAS PGRI PALEMBANG)
}

\author{
lulukirawan01@gmail.com ${ }^{1}$
}

\begin{abstract}
Abstrak-Masalah dalam penelitian ini yaitu adakah pengaruh media pembelajaran komik terhadap hasil belajar siswa akuntansi di SMK PGRI 1 Palembang tahun pelajaran 2019/2020. Metode yang digunakan adalah metode eksperimen. Teknik pengumpulan data yang digunakan adalah dokumentasi,observasi dan tes, serta teknik analisis data yang digunakan adalah regresi linier sederhana. Keaktifan siswa dalam proses pembelajaran dapat dilihat perbedaanya bahwa kelas eksperimen mencapai 74,19\% (Cukup Aktif) dan kelas kontrol mencapai 77,41\% (Cukup Aktif). Jumlah populasi dalam penelitian ini adalah seluruh siswa kelas X Ak dan kelas XI AK 1 yang berjumlah 92 siswa. Sampel dalam penelitian ini menggunakan teknik Sampel Random yaitu sampel acak, jumlah sampel yang didapat dalam penelitian ini sebanyak 62 siswa. Berdasarkan hasil pembahasan dapat disimpulkan bahwa diperoleh nilai ratarata hasil belajar kelas eksperimen yaitu 82,09\%, sedangkan nilai rata-rata hasil belajar kelas kontrol yaitu 63,93\%. Hasil analisis regresi linier sederhana diperoleh persamaan regresi: $Y=63,91+18,2 \mathrm{D}$, dari perhitungan diperoleh harga $t_{\text {hitung }}=8,708>t_{\text {tabel }}=2,000$, maka tolak Ho terima Ha dengan demikian terdapat pengaruh yang signifikan antara media pembelajaran komik terhadap hasil belajar siswa. Besarnya pengaruh antara media pembelajaran komik terhadap hasil belajar siswa adalah 55,7\% sedangkan sisanya sebesar 44,3\% dipengaruhi faktor lain.
\end{abstract}

Kata kunci: Media Pembelajaran Komik, Hasil belajar

Abstrak-The problem in this study is is there an influence of comic learning media on accounting learning outcomes at SMK PGRI 1 Palembang in the academic year 2019/2020. The method used is an experimental method. Data collection techniques used are documentation, observation and tests, and data analysis techniques used are simple linear regression. The activeness of students in the learning process can see the difference in the experimental class reaching 74.19\% (Enough Active) and the dick class reaching $77.41 \%$ (Enough Active). The number of participants in this study were all students of class X Ak and class XI AK 1 who denied 92 students. The sample in this study using a random sample technique that is a random sample, the number of samples obtained in this study were 62 students. Based on the results of the discussion it can be concluded that the average value of experimental class learning outcomes is $82.09 \%$, while the average value of the control class learning outcomes is $63.93 \%$. The results of a simple linear regression analysis obtained a regression equation: $Y=63.91+$ 
$18.2 \mathrm{D}$, from the calculation obtained tcount $=8.708>$ ttable $=2,000$, then reject Ho accept Ha thus, it needs to be discussed significantly between the media needed to learn learning about student learning outcomes The amount of interaction between learning media on student learning outcomes is $55.7 \%$ while the remaining $44.3 \%$ is another influence factor.

\section{Keywords: Comic Learning Media, Learning Outcomes}

\section{PENDAHULUAN}

Media pembelajaran terus berkembang sebagai usaha untuk meningkatkan kualitas pendidikan dan kualitas pembelajaran. Kemampuan guru dalam merancang pembelajaran yang mampu mengoptimalkan hasil belajar siswa merupakan kunci tercapainya tujuan pembelajaran. Media pembelajaran komik merupakan media yang berupa gambar, animasi atau tokohtokoh yang berbentuk kartun,untuk memainkan suatu cerita bersambung yang bersifat humor, serta ceritanya ringkas dan menarik perhatian. Sehingga dapat digunakan guru dalam media pembelajaran. Dengan demikian siswa akan termotivasi untuk belajar lebih giat yang pada akhirnya akan meningkatkan hasil belajar siswa sesuai dengan tujuan dari proses pembelajaran (tujuan instruksional) yang dapat dilihat nantinya di saat guru memberikan pelatihan kompetensi sesuai yang diharapkan atau dikuasai oleh siswa setelah mengikuti kegiatan pembelajaran dengan menggunakan media pembelajaran komik. Dalam pembelajaran ini selain kita menentukan media pembelajaran komik kita juga harus dapat melihat hasil belajar dari peserta didik tersebut. Hasil belajar merupakan suatu pencapaian yang diperoleh peserta didik dalam kegiatan belajar mengajar yang dilaksanakan oleh peserta didik tersebut dalam periode tertentu. Proses belajar mengajar merupakan inti dari kegiatan pendidikan di sekolah. Agar tujuan pendidikan dan pembelajaran berjalan dengan benar, maka perlu pengadministrasian kegiatankegiatan belajar mengajar. Tugas guru sebagai pendidik antara lain, yaitu menguasai dan mengembangkan materi pembelajaran, merencanakan dan menyiapkan pelajaran setiap hari, mengontrol dan mengevaluasi aktivitas belajar siswa khususnya dalam pembelajaran akuntansi. Kemampuan mengolah proses belajar mengajar merupakan kesanggupan atau kecakapan para guru dalam menciptakan suasana komunikasi yang edukatif antara guru dan peserta didik yang mencakup segi kognitif, efektif, dan psikomotor, sebagai upaya mempelajari sesuatu berdasarkan perencanaan sampai dengan tahap evaluasi dan tindak lanjut hingga tercapai tujuan pengajaran. Ketika 
media pembelajaran komik dapat digunakan guru sebagai alat bantu dalam proses pembelajaran kita dapat melihat hasilnya. Caranya guru harus menggunakan media yang dapat meningkatkan keaktifan dan keseriusan peserta didik dalam proses pembelajaran, yaitu dengan menggunakan media grafis salah satunya adalah media komik. Dengan demikian media komik dapat menciptakan suasana belajar menjadi kondusif dan menyenangkan, sehingga dapat meningkatkan hasil belajar peserta didik. Berdasarkan latar belakang di atas maka peneliti berkeinginan untuk mengadakan penelitian dengan judul " Pengaruh

Media Pembelajaran Komik Terhadap Hasil Belajar Siswa Akuntansi Di SMK PGRI 1 Palembang Tahun Ajaran 2019/2020.

\section{Rumusan Masalah}

Berdasarkan latar belakang di atas yang menjadi masalah dalam penelitian ini adalah: Apakah terdapat pengaruh media pembelajaran komik terhadap hasil belajar siswa akuntansi di SMK PGRI 1 Palembang tahun ajaran 2019/2020?

Tujuan yang diharapkan dalam penelitian ini adalah untuk mengetahui pengaruh media pembelajaran komik terhadap hasil belajar siswa akuntansi di SMK PGRI 1 Palembang tahun ajaran 2019/2020.

\section{METODOLOGI PENELITIAN}

Pengertian Media Pembelajaran

Menurut Sanjaya (2008:197).

Hakikat media pembelajaran "Dahulu, ketika teknologi khususnya teknologi informasi belum berkembang seperti saat ini, ketika ilmu pengetahuan belum sepesat ini proses pembelajaran biasanya berlangsung pada tempat dan waktu tertentu". Oleh karena itu, guru butuh alat yang dapat membantu proses belajar yaitu dengan media atau alat peraga pembelajaran.

Menurut Sanjaya (2008:205). Selain pengertian di atas, ada juga yang berpendapat bahwa media pengajaran meliputi perangkat keras (Hardware) dan perangkat lunak (Software). Hardware adalah alat-alat yang dapat mengantar pesan seperti Over Head, Projector, radio, televisi, dan sebagainya. Sedangkan Software adalah isi program yang mengandung pesan seperti informasi yang terdapat pada transparansi atau buku dan bahan-bahan cetakan lainnya, cerita yang terkandung dalam film atau materi yang disugukan dalam bentuk bagan, grafik, diagram, dan lain sebagainya.

\section{Macam-Macam}

Media

\section{Pembelajaran}

Menurut Sanjaya (2008:211212) Media pembelajaran dapat di klasifikasikan menjadi beberapa klasifikasi tergantung sudut pandang:

1) Dilihat dari sifatnya 
2) Dilihat dari kemampuan jangkauannya

3) Dilihat dari cara atau teknik pemakaiannya.

\section{Pengertian Media Pembelajaran Komik}

Menurut Sudjana \& Rivai (2017:63-64) menyatakan bahwa serial komik sangat erat hubungannya dengan kartun. Komik banyak ditemukan dinegara kita. Diperkirakan banyaknya pembaca komik di Amerika Serikat lebih dari seratus juta orang. Antara 400 sampai 500 judul komik terjual dan kurang lebih 95 juta kopi dijual pula setiap bulannya. Diterjemahkan kedalam lebih dari 30 bahasa, dan dibaca secara luas oleh lebih dari 100 negara. Suatu popularitas yang luar biasa dari komik-komiktersebut barang kali bisa dilihat dari besarnya jumlah orang-orang yang "mengonsumsinya" meliputi berjutajuta orang dari semua umur, untuk lelucon, kegembiraan serta hiburan. Baik pendidik atau bukan pendidik serta orang tua cenderung setuju dengan adanya komik sebagai media komunikasi.

\section{Komik Yang Digunakan Peneliti}

Komik yang digunakan sebagai media pembelajaran oleh peneliti adalah komik karya Ade Prahmadia Fuad program Studi Pendidikan Akuntansi Jurusan Pendidikan Akuntansi Fakultas Ekonomi Universitas Negeri
Yogyakarta 2016. Kontak pemilik komik :

Email prahmadia@gmail.com

Call : +6281227505785

Yang telah di uji oleh Ahli Materi, Ahli Media, Guru Akuntansi dan Siswa Akuntansi sebagaimana yang dijelaskan dalam skripsi onlinenya yang berjudul "Pengembangan Media

Pembelajaran Berbentuk Komik Untuk Meningkatkan Motivasi Belajar Akuntansi Pada Kompetensi Menyusun Laporan Keuangan Siswa Kelas X SMK Muhammadiyah 2 Moyudan Tahun Ajaran 2015/2016".

Berikut komik yang digunakan peneliti sebagai media pembelajaran yang berjudul "Laporan Keuangan Perusahaan Jasa" :
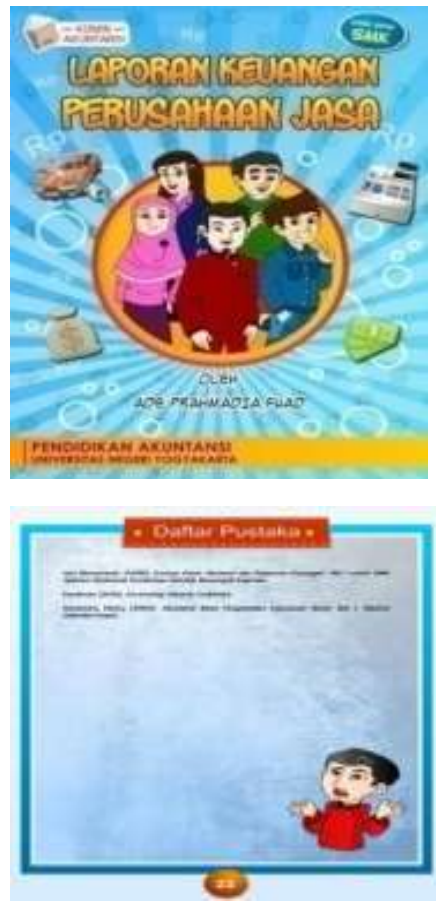


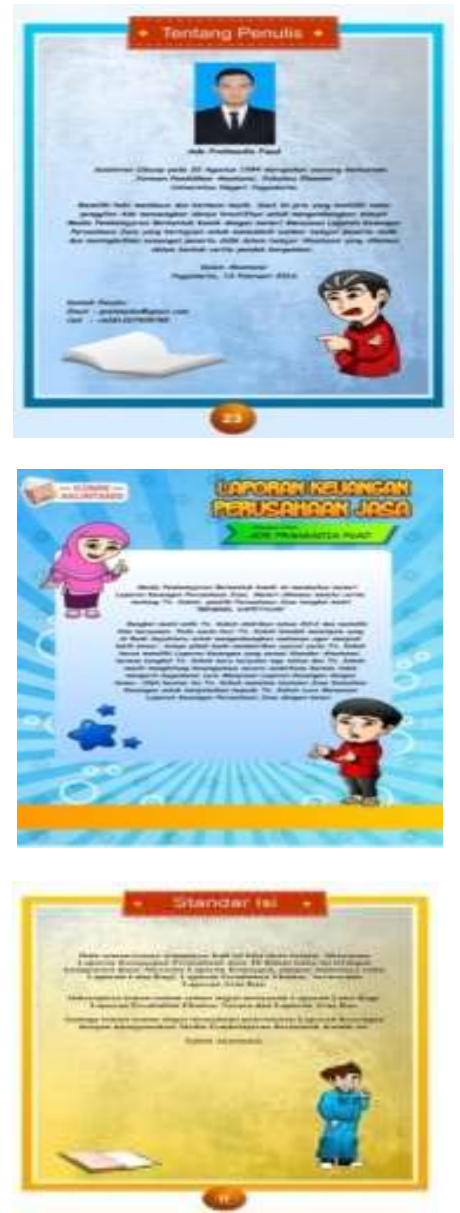

Metode yang digunakan dalam penelitian ini adalah metode eksperimen. "Metode eksperimen dapat diartikan sebagai metode penelitian yang digunakan untuk mencari pengaruh perlakuan tertentu terhadap yang lain dalam kondisi yang terkendalikan" (Sugiyono, 2014:72). Metode eksperimen dalam penelitian ini dilakukan dengan maksud untuk mengetahui perbandingan hasil belajar akuntansi siswa yang diajarkan menggunakan media pembelajaran komik pada kelas eksperimen dan kelas kontrol menggunakan sistem pembelajaran konvensional atau biasa.

\section{HASIL DAN PEMBAHASAN}

Hasil Penelitian Dikaitkan dengan Kajian Teori

$\begin{array}{lcr} & \text { Berdasarkan hasil } & \text { analisis } \\ \text { diatas, pengaruh hasil } & \text { belajar } \\ \text { tersebut } & \text { dikarenakan } & \text { dalam }\end{array}$
pelaksanaan proses pembelajaran pada kelas eksperimen yang diterapkan media pembelajaran komik, siswa diusahakan aktif dalam proses pembelajarannya. Kesan yang dialami siswa lebih mendalam dan tertanam dalam ingatan yang pada akhirnya berdampak pada peningkatan siswa tersebut dalam penguasaan materi yang diberikan. Sedangkan dalam pelaksanaannya proses pembelajaran yang dilakukan, hal ini berdampak pada siswa mengenai penguasaan materi yang diberikan.

Hal tersebut dikarenakan pada media pembelajaran komik, siswa berperan aktif dalam pembelajaran, baik dalam menentukan topik permasalahan maupun cara untuk menyelesaikannya. Kesuksesan media pembelajaran komik juga terbukti pada penelitian ini, ternyata dengan penerapan media pembelajaran komik, siswa dapat lebih aktif dalam proses pembelajaran dan berpengaruh terhadap kesungguhan siswa dalam proses belajar mengajar. Hal ini terlihat rata-rata hasil belajar yang diperoleh siswa melalui tes yang telah diberikan. 
Media pembelajaran adalah seluruh alat dan bahan yang dapat dipakai untuk tujuan pendidikan seperti radio, televisi, buku, koran, majalah, dan sebagainya. Sedangkan media pembelajaran komik adalah bentuk kartun,perwatakan sama membentuk cerita dalam urutan gambar-gambar yang berhubungan erat dan dirancang untuk menghibur para pembacanya.

Media pembelajaran komik baik diterapkan pada materi laporan keuangan, karena materi tersebut memberikan kesempatan bagi siswa untuk lebih aktif, mencari informasi dari pengalaman atau kejadian sehari-hari. Sedangkan media cetak, siswa hanya mendengarkan penjelasan peneliti kemudian mengerjakan tugas yang diberikan oleh peneliti.

Berdasarkan hasil distribusi hasil belajar kelas eksperimen yang memperoleh nilai pada kriteria "Baik Sekali” sebesar 22,58\%, yang memperoleh nilai pada kriteria "Baik" sebesar 70,97\%, yang memperoleh nilai pada kriteria "Cukup" sebesar 6,45\% dan tidak ada yang memperoleh nilai pada kriteria "Kurang" dan "Kurang Sekali". Rata-rata nilai hasil belajar siswa pada kelas eksperimen adalah sebesar 82,09\%. Sedangkan hasil distribusi hasil belajar kelas kontrol yang memperoleh nilai pada kriteria "Baik" sebesar 19,36\% yang memperoleh nilai pada kriteria "Cukup" sebesar 74,19\%, yang memperoleh nilai pada kriteria "Kurang" sebesar 6,45\% dan tidak ada yang memperoleh nilai pada kriteria "Baik Sekali" dan "Kurang Sekali”. Rata-rata nilai hasil belajar siswa pada kelas kontrol adalah $63,93 \%$. Berdasarkan penelitian yang dilakukan peneliti memperoleh nilai $t_{\text {hitung }}=8,708>$ dari $t_{\text {tabel }}=2,000$ berarti tolak Ho dan terima $\mathrm{H} \alpha$ maka hipotesis penelitian berbunyi ada pengaruh yang signifikan media pembelajaran komik terhadap hasil belajar siswa akuntansi di SMK PGRI 1 Palembang.

\section{Hasil Penelitian Dikaitkan dengan Kajian Penelitian Relevan}

Berdasarkan hal tersebut maka senada dengan pendapat Caesalpinia, dkk (2018) yang menyatakan ada pengaruh penerapan media komik terhadap hasil belajar siswa pada mata pelajaran keterampilan menulis biografi di SMA Budi Utomo Perak tahun ajaran 2017/2018. Terbukti dapat diketahui bahwa data $t_{\text {hitung }}=4,853$ dengan $t_{\text {tabel }}=1,681$, karena $t_{\text {hitung }}$ lebih besar dari pada $t_{\text {tabel, }}$ yaitu 4,853 > 1,681, maka $\mathrm{H}_{1}$ diterima.

Selain itu juga sejalan dengan pendapat Bubin Florayu, dkk (2017) yang menyatakan terdapat pengaruh media pembelajaran komik terhadap hasil belajar siswa pada mata pelajaran matematika di SMP N 10 Palembang. Terbukti dari hasil pengujian hipotesis menunjukkan setelah belajar t-test media appliec 
komik showec belajar $=1,14>$ tabel $=1,667$ sehingga hipotesis nol $(\mathrm{Ho})$ diterima.

$$
\text { Hasil analisis dalam }
$$
penelitian ini menunjukkan bahwa terdapat pengaruh media pembelajaran komik terhadap hasil belajar siswa pada mata pelajaran laporan keuangan di SMK PGRI 1 Palembang. Hasil perhitungan hasil belajar siswa yang memperoleh dari nilai tes diperoleh nilai tertinggi pada kelas eksperimen yaitu sebesar 100 dan yang terendah 61, diperoleh ratarata hasil belajar siswa sebesar $82,09 \%$. Terdapat 7 siswa dengan persentase $22,58 \%$ pada kriteria "Baik Sekali" , 22 siswa dengan persentase $70,97 \%$ pada kriteria "Baik" dan 2 siswa dengan persentase $6,45 \%$ pada kriteria "Cukup". Sedangkan nilai tertinggi pada kelas kontrol yaitu 80 dan yang terendah 47, diperoleh rata-rata sebesar 63,93\%. Terdapat 6 siswa dengan persentase $19,36 \%$ pada kriteria "Baik", terdapat 23 dengan persentase $74,19 \%$ pada kriteria "Cukup", terdapat 2 siswa dengan persentase $6,45 \%$ pada kriteria "Kurang".

Penelitian menggunakan rumus uji $\mathrm{t}$ dengan hasil perhitungan diperoleh harga $t_{\text {hitung }} 8,708>$ dari $\mathrm{t}_{\text {tabel }}=2,000$ berarti tolak Ho dan terima $\mathrm{H} \alpha$ maka ada pengaruh yang signifikan media pembelajaran komik terhadap hasil belajar siswa yaitu sebesar 82,09\% sedangkan sisanya sebesar $63,93 \%$ dipengaruhi faktor lain.

Dari uraian di atas maka dapat diartikan bahwa penerapan media pembelajaran komik dapat meningkatkan hasil belajar siswa.

\section{KESIMPULAN DAN SARAN Kesimpulan}

Berdasarkan hasil penelitian tentang pengaruh media komik terhadap hasil belajar siswa di SMK PGRI 1 Palembang maka disimpulkan bahwa:

Keaktifan siswa dalam proses pembelajarandengan media komik. Pada kelas eksperimen mencapai 74,19\% (Cukup Aktif). Dan kelas kontrol mencapai 77,41\% (Cukup Aktif). Dan hasil belajar siswa pada kelas eksperimen rata-rata hasil belajar sebesar 82,09\%. Dan pada kelas kontrol rata-rata hasil belajar sebesar 63,93\%. Berdasarkan hasil uji hipotesis maka, terdapat pengaruh media pembelajaran komik terhadap hasil belajar siswa akuntansi di SMK PGRI 1 Palembang. Yaitu 55,7\% sedangkan sisanya sebesar $44,3 \%$ dipengaruhi faktor lain.

\section{DAFTAR PUSTAKA}

Apriyanti, f. (2012). Pengaruh pemanfaatan media komik matematika terhadap hasil belajar kelas V SSDN 24 pontianak tenggara. Skripsi .

Arikunto, S. (2014). Prosedur Penelitian Suatu Pendekatan Praktik. Jakarta: Rineka Cipta. 
Avrilliyanti, d. (2013). Jurnal Pendidikan Fisika. Penerapan Media Komik Untuk Pembelajaran Fisika Model Kooperatif Dengan Metode Diskusi Pada Siswa SMP Negeri 5 Surakarta Kelas VII Tahun Ajaran 2011/2012 Materi Gerak, Vol. 1, No. 1.

Basir, A. (2017). Pengantar Metode Penelitian Pendidikan. Palembang: UPT. Penerbit Dan Percetakan Universitas Sriwijaya.

Daryanto. (2010). Media Pembelajaran. Yogyakarta: Penerbit Gava Media.

Dimyati Dan Mudjiono (2006). Belajar Dan Pembelajaran. Bandung: Rineka Cipta

Enawaty, E. d. (2010). Pengaruh Penggunaan media komik terhadap hasil belajar siswa kelas $\mathrm{X}$ SMA Negeri 3 pontianak materi larutan elektrolit dan nonelektrolit. Jurnal penelitian, vol 1, no 1.

Florayu, B. d. (2017). Pengaruh Penggunaan Media Pembelajaran Komik Terhadap Peningkatan Hasil Belajar Matematika Siswa Kelas VII Di SMP Negeri 10 Palembang. Jurnal Musharafa, vol 6, no 1.

Harahap, S. S. (2011). Teori Akuntansi. Jakarta: Rajawali Pers.

Mediawati, E. (2011). Jurnal Penelitian Pendidikan. Pembelajaran Akuntansi Keuangan Melalui Media Komik Untuk Meningkatkan Prestasi Mahasiswa, Vol. 12, No. 1.

Nazir, M. (2014). metode penelitian. bogor: ghalia indonesia.
Nurkhalisyah, M. (2018). Jurnal Penelitian Pendidikan. Pembuatan Buku Komik Panduan Perpustakaan Di Perpustakaan Daerah Kota Padang Panjang, Vol. 7, No. 1.

Nurohimah, d. Jurnal Penelitian Pendidikan. Pemanfaatan Kartun Fisika Sebagai Media Pembelajaran Untuk Meningkatkan Motivasi Belajar Pada Siswa Kelas VII Mts N Purworejo, Vol. 1, No. 1.

Parwati, N. N. (2018). Belajar Dan Pembelajaran. Depok: Rajawali Pers.

Penyusun, T. (2018). pedoman penulisan skripsi tahun akademik 2018/2019. palembang: FKIP Universitas PGRI Palembang.

Permana, d. (2009). Ekonomi 2. Jakarta: Pusat Perbukuan.

Pramadi, I. P. (2013). Pengaruh penggunaan komik berorientasi kearifan lokal bali terhadap motivasi belajar dan pemahaman konsep fisika. Jurnal program pascasarjana , vol 3 .

Purwanto. (2016). evaluasi hasil belajar. yogyakarta: pustaka belajar.

Riduwan. (2013). belajar mudah penelitian. bandung: alfabeta.

Rifqy, M. (2018). Jurnal Pendidikan Bahasa \& Sastra Indonesia. Pengaruh Media Visual Komik Terhadap Hasil Belajar Keterampilan Menulis Teks Biografi Pada Siswa Kelas X MIPA 12 SMA Budi Utomo Perak Tahun Ajaran 2017/2018, Vol. 6, No. IV. 
Rohani, A. (2014). Media Instruksional Edukatif. Jakarta: Rineka Cipta.

Sadiman, d. (2014). Media Pendidikan. Jakarta: Rajawali Pers.

Sanjaya, W. (2008). Perencanaan Dan Desain Sistem Pembelajaran. Jakarta: Kencana Prenada Media Group.

Saputro, h. b. (2015). Pengembangan media komik berbasis pendidikan karakter pada pembelajaran tematik-integratif kelas IV SD. Jurnal prima edukasia, vol 3, no 1.

Sianipar, E. M. (2016). statistik analisis regresi dan korelasi. palembang: noer fikri.

Siwi, Y. H. (2009). Skripsi Penelitian Pendidikan. Eksperimentasi Pengajaran Matematika Dengan Menggunakan Media Komik Ditinjau Dari Minat Belajar Siswa .

Sudjana, R. (2017). Media Pengajaran. Bandung: Sinar Baru Algensindo.

Sugiyono. (2018). Metode Penelitian Kuantitatif, Kualitatif, Dan $R \& D$. Bandung: Penerbit Alfabeta. 